\title{
TAX PLANNING IN THE ENTERPRISE MANAGEMENT SYSTEM
}

\author{
OLHA ZHUK, ANTONINA TOMASHEVSKA
}

\begin{abstract}
The differences between the concepts of "tax planning", "tax minimization" and "tax optimization" are investigated and it is established that tax minimization is the maximum reduction of all taxes, tax optimization is the achievement of a propor tion between all aspects of an entity's activity; tax planning The system of measures of the enterprise is directed to the maximum use of the current legislation for the purpose of legal optimization of payments. It has been determined that the ways to reduce the tax burden include tax benefits, preferential taxation and the possibility of choosing a simplified system of taxation by small business entities. The levels and requirements to be followed in tax planning are identified and substantiated: organization of accounting and tax accounting, examine tax law, determine the list of benefits, correct accrual and timely payment, using legal methods to reduce the tax burden.

The methods which are applied in tax planning are substantiated: current internal control, preliminary tax examination, comparative analysis.

It is determined that tax planning is influenced by certain factors: the sphere of the activity in which the entity operates, the types of activity it is engaged in; status of belonging to a legal or natural person; the purpose of tax planning and the possibility of applying tax benefits. The tax planning system should be formed in accordance with principles: compliance with tax law; justification of the feasibility of applying the tax system; prompt response to changes in tax law; use of tax planning methods; use favorable tax regimes. Tax planning spends efforts on the following functions: analytical, accumulation, distribution, control.

It is established that the assessment of the effectiveness of the enterprise tax policy should be made through a system of indicators: the level of tax burden on the enterprise; the level of influence of tax planning on the magnitude of the enterprise's tax liabilities and the effectiveness of the enterprise's tax planning and tax policy in general. Effectively organized tax policy at the enterprise will help improve the results of the enterprise. Tax planning should be an integral part of the overall planning of the enterprise.
\end{abstract}

Keywords: tax planning, tax minimization, tax optimization, tax evasion.

\section{INTRODUCTION}

In today's business environment, businesses need to develop a tax policy that takes into account the features of the business entity, its development trends and the impact of each tax on the indicators of the financial condition of the enterprise.

Nowadays, taxes are a significant factor in influencing the financial and economic activity of an enterprise. Therefore, to ensure the proper functioning of business structures in an unstable socio- 
economic environment, and quality management of financial resources, managers and accountants can only in the presence of their developed concept of tax management. Effectively organized tax policy and tax planning at the enterprise will contribute to the stable financial condition of the enterprise, as well as timely fulfillment of their obligations to the budget. Enterprise-level tax planning is the choice between various financial and economic activities and the placement of an asset in order to achieve the lowest possible level of tax liabilities that arise.

Some questions of tax planning were investigated by the following scholars: Bilyk M., Vasilik O., Vilkova O., Danilov O., Eliseyeva A., Zagorodnyi A., Zolotko I., Kovalchuk K., Melnyk D., Onishchuk Yu, Podluzhny M., Pogorletsky A., Romanovsky M., Usenko L. and others. However, at present there is no single approach to determining tax planning, implementing the tax optimization scheme, principles and methods of organizing tax planning at the enterprise, which led to the choice of research direction.

The main purpose of the research is to determine the essence of tax planning, determine the principles, levels and need for tax planning at the enterprise

\section{RESULTS}

The prerequisites for the emergence and development of tax planning are: the objective nature of the existence of taxes and the tax system; orientation of enterprises on increase of profit; the objective need to adapt to the volatility of the environment and the conditions of market competition.

In defining the concept of tax planning, A. Porsnev asserts that it is a process of preliminary review and evaluation of decisions in the field of financial activity of the organization, taking into account the magnitude of possible tax payments and ensuring the choice of the best decisions from the point of view of the general target units of the organization [1].

M. Romanovskiy cites a close definition of tax planning. He believes that tax planning at the level of the entity is an integral part of managing its financial activities within a single strategy for its economic development, which is a process of systematic use of optimal legal tax methods and methods to determine the desired future financial status of an object in conditions of limited resources and the possibility of their alternative use" [2].

Considering the targeting of tax planning and its impact on the optimization of tax payments, let us consider the position of A. Yeliseyev and A. Zagorodnyi that the first conceptual approach defines the concept of tax planning, and the second - tax planning. The first should be understood as the budgeting of taxes, and accordingly under tax planning optimization of tax payments [3].

It should be noted that L. Usenko under tax planning at the micro level understands the purposeful activity of the business entity, which is carried out by means of aggregate planning actions, united in a single system and involves the choice of optimal options for financial economic activity [4].

In foreign publications, under tax planning, a special organization of taxpayer activity is considered in order to optimize its tax liabilities for a long time in ways that are not related to violation of current legislation $[5,6]$.

The interpretation of tax planning cited by $\mathrm{Yu}$. Onishchuk is worth too. He believes that the tax planning organization is the most optimal from a tax point of view in a way that allows you to optimize the tax obligations of the company in the right ways and means.

$\mathrm{Yu}$. Onishchuk distinguishes between the components of tax planning. At the same time, he considers tax optimization as the main component of tax planning, and minimization of payments as one of the options of tax optimization, the application of which is possible only within certain limits and subject to com pulsory observance of other conditions [7].

It follows that tax minimization and optimization are not the same thing.

Tax minimization is the maximum reduction of all taxes, and tax optimization is a process that is related to the achievement of certain proportions of all aspects of business entities in general.

The above analysis makes it universal that tax planning consistents with various forms of enterprise tax policy implementation. In this case, tax planning should be considered as tax budgeting, and tax 
planning at the micro level can be defined as a system of measures of the enterprise, which is aimed at maximizing the use of existing legislation to optimize tax payments.

The tax legislation does not specify which actions are lawful and which are illegal, so the taxpayer must adhere to the rules and principles of the tax legislation independently, avoiding fraudulent transactions, so that they can not be interpreted as "tax evasion". Full or partial non-payment of taxes can be done both legally and it means using the features of the current legislation, and illegally, so it means in violation of the law [8]. There is no clear definition of economic concepts in the economic literature so far. If the tax authorities use the term "evasion" for both legal and illegal tax cuts or nonpayment, economists propose to call the legal reduction of taxes the term "tax planning", and illegal the term "evasion".

Some experts equate legal optimization of tax payments to tax evasion. In our view, this identification of the conceptual apparatus is incorrect. The concepts of tax planning and tax evasion should be clearly distinguished by the criterion of legality.

In taxation theory, there are three ways to avoid paying taxes.

1. Tax evasion, which means unlawful use by a business or individual of tax breaks, late payment of taxes, concealment of income, failure to submit or late submission of documents necessary for timely calculation and payment of taxes

2. By passing taxes for which the enterprise or individual is not a payer, or its activities are not taxable, or its income is not taxed. The enterprise may also use illegal methods, such as the lack of registration, accounting for tax objects.

3. Tax planning, in which legal and natural persons are active tax policy, aimed at minimizing the negative impact of taxation by methods that are not contrary to the law.

In our view, the purpose of tax planning is to choose the way in which tax payments would be minimal.

Because tax payments are an expense item, tax planning can be considered as an element of an overall cost optimization strategy. However, the accrual and payment of taxes are functionally unrelated to production, and taxes are in any case a simple deduction from the income of an entrepreneur, whom he naturally wants to avoid. There are two ways to achieve this:

- use all legal possibilities to reduce their tax payments and transform their activities so that the resulting tax liabilities are minimal;

- use illegal ways to reduce tax liabilities while trying to conceal their activities from tax authorities by misrepresenting tax reporting and misrepresenting their actions and income.

In summary, we believe that the essence of tax planning is to formulatean enterprise tax policy that would provide the most optimal option for financial activities and placement of their assets to achieve the lowest level of tax payments.

In our opinion, compliance with the law should be based on an understanding of the ambiguity of interpretations of the main provisions of the legislative acts.

Taxes are inherently compulsory and irrevocable recovery in favor of the state of part of the assets (cash) of the taxpayer governed by tax laws. They are one of the cost items that reduce the net profit of the enterprise [2]. Therefore, any action by the taxpayer to use all legitimate methods of reducing costs, including tax payments, to increase their profits is legitimate.

The main features of tax evasion: concealment of revenue, formal increase in the number of employees; illegal creation of new organizations; conducting business without registration of the subject of economic activity; increase of expenses in economic activity is not confirmed; abuse of selfinterest.

Tax Planning is the planning of optimizing tax payments and fees through legitimate means. Tax planning does not go beyond the limits of the law, everything is done within the law. Creating a system of efficient and secure tax planning becomes possible provided that the rules of tax legislation and the lawfulness of their disclosure are taken into account [9, p. 350]. In developed countries, tax planning 
ranks first in the financial planning of an enterprise. Tax planning should be an integral part of the overall planning of the enterprise.

Because tax law provides different types of tax regimes, the company can reduce the tax burden and systematize the procedure for tax collection.

Tax legislation, laying the foundations for granting tax benefits, identifies categories of taxpayers as privileged entities, rather than individual legal entities or individuals, that is, allocates a certain homogeneous group of taxpayers, characterized by a specific feature, on the basis of which the tax regime. All other taxpayers determine the subject of taxation, calculate the tax base and the amount of allowances in full in accordance with the general rules established by law.

The grounds for granting tax benefits are the characteristics that characterize a particular group of taxpayers, the type of their activity and the object of taxation.

The tax burden can be reduced by applying:

- preferential taxation of agricultural producers - for agricultural enterprises - provides for a fixed agricultural tax;

- simplified tax system for small business entities;

- tax privileges - exemption of the taxpayer from the obligation to charge and pay tax and levy, pay it tax and levy in a smaller amount if there are grounds.

The tax benefit is provided by:

1) tax deduction (discounts), which reduces the tax base before tax and collection;

2) reduction of tax liability after tax and collection;

3) setting a reduced rate of tax and levy;

4) tax exemption and levy [10, p. 37].

Thus, entities can apply a simplified system of accounting and reporting taxation, which involves the replacement of a number of taxes and fees established by law by payment of a single tax.

Carrying out tax planning at the enterprise should start with the choice of the scheme under which the enterprise will operate or a separate business operation will be conducted. Tax optimization schemes are a tool that can overcome the negative tax consequences and make them profitable for both taxpayers and the budget [11]. An entity must have a choice of tax planning schemes to understand which one to apply depending on the situation.

Global schemes can optimize most long-term tax payments.

Local schemes allow you to optimize multiple taxes for a limited time.

Dynamic local schemes allow to maneuver the amount of savings when changing the object of taxation [11].

Tax planning provides for different tax conditions depending on:

- the branch (spheres of activity) in which the economic activity is carried out;

- the size of the economic entity (small or large);

- kind of activity;

- status of belonging to a legal or natural person;

- why you need tax planning (to optimize a particular transaction or all business activities);

- the existence of tax benefits.

Tax planning involves several levels, each with specific requirements:

1. Organization of accounting and tax accounting - will allow timely and full receipt of reliable information for tax planning;

2. Examine tax law - Knowledge of tax law will determine the impact of the tax system on the economic activity of enterprises, as well as each tax in particular;

3. Determine the list of benefits that can be applied by the business entity.

4. Correct accrual and timely payment of tax payments - correct accrual and timely payment of tax payments will avoid application of financial penalties and accrual penalties for late and incomplete payment of payments;

5. Optimal tax payments - is planning the optimal ratio of income and expenses in one tax period;

6. Pay minimally, using legal methods to reduce the tax burden. 
When planning, first of all, it is necessary to examine what impact on the financial result of the enterprise has a tax and for what purpose and for what period tax planning is carried out.

The tax planning can be carried out using the following methods:

1. Current internal control (short-term operational tax planning) is a periodic control over taxes and payments, comparing actual tax payments with short-term projections. Analyze and identify the causes of discrepancies between estimates and actual payments and develop proposals to address them.

2. Previous tax expertise (mid-term forward-looking tax planning) involves the examination of new projects and major management decisions. This method assumes that the enterprise has an information-analytical base on taxes.

3. Benchmarking (long-term strategic tax planning) involves analyzing new enterprise activity projects as a whole. In accordance with this method, a comparison of different options for the activity of the enterprise to determine their tax efficiency: for a short period and for long periods of activity.

The tax planning system at the enterprise should be formed and refined in the light of the following basic principles :

1. Knowledge and compliance with tax laws;

2. The feasibility of applying the selected tax system;

3. Rapid response of taxpayer to changes in tax legislation;

4. Using different methods of tax planning, taking into account the particular activities of a particular taxpayer.

5. Use of favorable tax regimes.

Tax planning spends efforts on the following functions:

- analytical - economic analysis of the use of financial resources for previous periods, the definition and mobilization of internal financial capabilities;

- accumulation - providing the enterprise with the necessary financial resources;

- distribution - optimal distribution of income and accumulation;

- control - managing over economic and financial activities.

The underestimation of the role of planning in Ukraine explains the lack of knowledge by many managers of modern terms and new approaches to managing the financial resources of enterprises. A tax system is effectively organized to optimize tax payments. Coherence of activities and optimization of this system in the direction of minimizing taxes legally reduces the financial expenses and strengthens the financial condition of the enterprise as a whole.

Increasing importance of economic levers of enterprise management implies the use of optimal approaches to tax planning and evaluation of its effectiveness.

The quantitative assessment of the effectiveness of the tax policy implemented by the company should be done through a system of well-known indicators, which determine:

- the level of tax burden on the enterprise;

- the level of influence of individual tax planning measures on the size of the enterprise's tax liabilities;

- efficiency of enterprise tax planning and tax policy in general.

Tax planning, in conjunction with management functions, is one of the main tools for generating performance indicators for the enterprise, since the calculation of the latter without regard to tax consequences is reckless and irrational. Thus, tax planning should become a mandatory tool in the set of management of a domestic enterprise when making a management decision.

Smart tax planning allows you to legally optimize your tax payments based on a thorough study of tax law and business organization to meet the requirements of tax optimization. 


\section{CONCLUSIONS}

Nowadays, taxes represent a significant share in the costs of an enterprise, and thus have a significant impact on the enterprise. Under such conditions, only a well-organized tax policy at the enterprise will help to increase the results of the enterprise's activity, its stable development and fulfill its obligations to the budget for taxes and payments. Properly organized enterprise tax planning will allow the taxpayer to minimize tax liabilities, increase profits and avoid penalties.

\section{REFERENCES}

[1] Porshnev A.G., Chernik D.G., Zamyatin B.I., Kirova E.A., Morozov V.P., Nesterova N.A., Shmelev Yu.D. Tax Management: textbook. INFRA-M, Moscow, 2003. (in Russian)

[2] Vilkova E., Romanovsky M. Tax planning. Pyter, St. Petersburg, 2004. (in Russian)

[3] Yeliseyev A.V., Zavgorodniy A.H. Tax planning in the system of financial management of the enterprise. Finanse of Ukraine, 8 (2009), 131-134. (n Ukrainian)

[4] Usenko L.M. Methods of improving tax planning at the enterprise. State and regions. Series: Economics and Enterprise, 2 (2006), 417-421. (in Ukrainian)

[5] Barulin S.V., Ermakova E.A., Stepanenko V.V. Tax management. Finance and statistics, Moscow, 2010. (in Russian)

[6] Lykova L.N., Bukina I.S. Tax systems of foreign countries. KNORUS, Moscow, 2012. (in Russian)

[7] Onishchuk $\mathrm{Yu}$. Tax planning the right of organization of the taxpayer in the fulfillment of tax obligations. Entrepreneurship, Economy and Law, 9 (2007), 59-61. (in Ukrainian)

[8] Barabanova V.V. Theoretical aspects of tax planning of enterprises. Investment: Practice and Experience, 2 (2013), 115 -117. Available at: http://www.investplan.com.ua/pdf/2_2013/30.pdf (in Ukrainian)

[9] Suprunenko S.A. Improvement of tax planning in the interests of the state and the enterprise. Theoretical and Practical Aspects of Economics and Intellectual Property, 8 (2009), 349-352. (in Ukrainian)

[10] "The Tax Code of Ukraine from 23.12.2010 № 2856-VI". Available at: http://sfs.gov.ua/nk/ (in Ukrainian)

[11] Ivanov Yu.B., Karpova V.V., Karpov L.N. Tax planning: principles, methods, tools. INJEC, Kharkiv, 2006. (in Russian)

Address: Olha Zhuk, Antonina Tomashevska, Vasyl Stefanyk Precarpathian National University, 57, Shevchenko Str., Ivano-Frankivsk, 76018, Ukraine.

E-mail: zhuk.oi82@gmail.com, lianeta@i.ua

Received: 17.09.2019; revised: 05.12.2019.

Жук Ольга, Томашевська Антоніна. Податкове планування у системі управління підприемством . Журнал Прикарпатського університету імені Василя Стефаника, 6 (3-4) (2019), 96-102.

Досліджено відмінності між поняттями “податкове планування", “податкова мінімізація" та “оптимізація оподаткування" й встановлено, що податкова мінімізація це максимальне зниження всіх податків, податкова оптимізація - досягнення пропорції між усіма аспектами діяльності суб'єкта господарювання; податкове планування система заходів підприемства спрямована на максимальне використання чинного законодавства з метою законної оптимізації платежів. Визначено, що до 
шляхів зменшення податкового навантаження відносяться податкові пільги, пільгове оподаткування та можливість вибору спрощеної системи оподаткування суб'єктами малого підприємництва. Визначено та обгрунтовано рівні та вимоги, яких потрібно дотримуватися при здійсненні податкового планування: організація бухгалтерського та податкового обліку, вивчення податкового законодавства, визначення пільг, правильне нараховування та своєчасна сплата податків, застосовування законних методів зменшення податкового навантаження.

Обгрунтовано методи, які потрібно застосовувати при податковому плануванні: поточний внутрішній контроль, попередня податкова експертиза, порівняльний аналіз.

Визначено, що на податкове планування впливають певні фактори: сфера діяльності, у якій функціонує суб'єкт господарювання, види діяльності, якими замається; статус принадежності до юридичної чи фізичної особи; мета податкового планування та мождивість застосування податкових пільг.

Система податкового планування повинна формуватися 3 урахуванням принципів: дотримання податкового законодавства; обгрунтування доцільності застосування системи оподаткування; оперативне реагування на зміни у податковому законодавстві; використання методів податкового планування; використання сприятдивих податкових режимів.

Податкове планування спрямовуе зусилля на виконання таких функцій: аналітичної, нагромадження, розподілення, контрольної.

Встановлено, що оцінку ефективності податкової подітики підприємства потрібно проводити через систему показників: рівень податкового навантаження на підприємство; рівень впливу податкового планування на ведичину податкових зобов'язань підприємства та ефективність податкового планування та податкової політики підприємства загалом. Ефективно організована податкова політика на підприемстві сприятиме підвищенню результатів діяльності підприємства. Податкове планування повинно бути невід'ємною частиною загального планування діяльності підприемства.

Кдючові слова: податкове планування, мінімізація податків, оптимізація податкових платежів, ухилення від сплати податків. 